\title{
Imagens e textos de propaganda sobre a União Soviética na revista Die Wehrmacht (Berlim, 1939-1944)
}

João Arthur Ciciliato Franzolin*

\section{RESUMO}

Este artigo analisa como a linha editorial da revista Die Wehrmacht (órgão oficial das Forças Armadas alemãs) alterou-se significativamente antes e durante o desenrolar da guerra na frente leste na Segunda Guerra Mundial. A princípio favorável aos "russos", logo passou a atacar veementemente a Uniáo Soviética em suas reportagens, mas mesmo assim chegou a reconhecer a superioridade militar da URSS após a derrota em Stalingrado. A publicação iniciada em 1936 tornou-se um sucesso editorial na Alemanha nazista e alguns países ocupados, atingindo a tiragem de quase dois milhôes de exemplares no ano de 1944. Ao mesmo tempo, cumpre explicar a materialidade da publicação, a atuação das chamadas Companhias de Propaganda (Propagandakompanien, PK), as quais produziam material propagandístico para a revista, e do aparato governamental responsável pelo controle do periódico, como o Departamento de Propaganda da Wehrmacht (WPr.) e o Ministério da Propaganda e Esclarecimento Popular (RMVP).

Palavras-chave: Die Wehrmacht; Companhias de Propaganda; propaganda nazista; imprensa ilustrada; Segunda Guerra Mundial.

\section{Images and propaganda texts about the Soviet Union in Die Wehrmacht magazine (Berlin, 1939-1944)}

\section{ABSTRACT}

This article analyzes how the editorial section of the magazine Die Wehrmacht (the official publication of the German Armed Forces) changed significantly over the course of World War II. At first favorable to Russia, it soon began to vehemently attack the Soviet Union

DOI: http://dx.doi.org/10.1590/2237-101X02204710

Artigo recebido em 5 de maio de 2020 e aceito para publicação em 20 de julho de 2020.

* Pesquisador da Europa-Universität Flensburg, Institut für Gesellschaftswissenschaften und Theologie, Flensburg - Alemanha. E-mail: joaoarthurfranz@gmail.com. ORCID: https://orcid.org/0000-0003-31551510. 
(USSR), even though it recognized the military superiority of the USSR after the German Army's defeat at Stalingrad. The publication began in 1936, and thereafter it became an editorial success in Nazi Germany and in some occupied countries, reaching a print run of almost two million copies in 1944. This article explores the publication's materiality, the role of the so-called Propaganda Companies (Propagandakompanien) that produced propagandistic material for the magazine, and the government agencies responsible for the publication, such as the Wehrmacht Propaganda Department and the Ministry of Propaganda and Popular Enlightenment.

Keywords: Die Wehrmacht; propaganda companies; Nazi propaganda; illustrated press; Second World War.

\section{Imágenes y textos de propaganda sobre la Unión Soviética en la revista Die Wehrmacht (Berlín, 1939-1944)}

\section{RESUMEN}

Este artículo analiza cómo la línea editorial de la revista Die Wehrmacht (ógano oficial de las Fuerzas Armadas Alemanas) se alteró significativamente antes y durante el desarrollo de la guerra en el frente este en la Segunda Guerra Mundial. En un principio favorable a los "rusos", luego pasó a atacar vehementemente a la Unión Soviética en sus reportajes, sin embargo, llegó a reconocer la superioridad militar de la URSS después de la derrota en Stalingrado. La publicación iniciada en 1936se volvió un éxito editorial en la Alemania nazi y algunos países ocupados, alcanzando el tiraje de casi dos millones de ejemplares en el año 1944. Al mismo tiempo, debe explicar la materialidad de la publicación, la actuación de las llamadas Compañías de Propaganda Propagandakompanien, PK), las cuales producían material propagandístico para la revista y del aparato gubernamental responsable por el control del periódico, como el Departamento de Propaganda de la Wehrmacht (WPr.) y el Ministerio de la Propaganda y Esclarecimiento Popular (RMVP).

Palabras clave: Die Wehrmacht; compañías de Propaganda; propaganda nazi; prensa ilustrada; Segunda Guerra Mundial.

No decorrer das últimas duas décadas foram lançadas na Alemanha algumas obras que contemplavam um campo historiográfico até então pouco explorado naquele país: revistas publicadas durante os doze anos de domínio nazista. Dentre as contribuiçôes mais importantes destaca-se o caso da revista Signal (Berlim, 1940-1945), impressa em 25 línguas diferentes, e que se tornou um sucesso editorial, com quase 2,5 milhôes de exemplares por 
edição, vendidos em toda a Europa ocupada e nos países neutros durante a Segunda Guerra Mundial (RUTZ, 2007). Outro exemplo da produção historiográfica alemã atual é o livro de Wenke Nitz que trata das representações da encenação do poder em revistas ilustradas alemãs e italianas do período (NITZ, 2013), bem como a obra de Harriet Scharnberg sobre o antissemitismo em reportagens da imprensa ilustrada (SCHARNBERG, 2018) e a de Dussel, que aborda estratégias de utilização da iconografia em revistas germânicas do início do século XX até 1945 (DUSSEL, 2019). Neste recente interesse insere-se, ainda, tese sobre a revista Die Wehrmacht, órgão oficial das Forças Armadas durante a ditadura nazista.

Tendo em vista essa produção, objetiva-se analisar temas de propaganda e estereótipos acerca da Uniáo Soviética em textos, fotos e desenhos publicados durante a Segunda Guerra Mundial em Die Wehrmacht, tomada como fonte e objeto. A noçáo criada pelo historiador alemão Thymian Bussemer é adequada para compreender o que se entende aqui por propaganda:

é em regra a formação geralmente mediada pela mídia de opinióes e atitudes relevantes para a açáo de grandes grupos políticos ou sociais, e pode ser entendida através da comunicaçáo simbólica e como fabricação de opiniáo pública em favor de certos interesses. A propaganda é caracterizada pela complementaridade da excessiva autodenúncia e denúncia da imagem externa e subordina a verdade ao critério instrumental da eficiência. Ela tenta naturalizar suas mensagens e açōes de apelo, de forma que estas apareçam como conclusōes intuitivas e óbvias (BUSSEMER, 2008, p. 33). ${ }^{1}$

Em relaçâo à materialidade da revista serão utilizadas as reflexôes de Tania Regina de Luca, já conhecidas na historiografia brasileira. A autora postula (LUCA, 2005) a importância da análise dos objetivos de uma publicaçáo e de seus fundadores, colaboradores e apoiadores (aspectos externos), bem como a identificação do seu público alvo e ainda aspectos externos de um periódico, tais como paginação, periodicidade e outros, que também possuem intençôes de convencimento do leitor (LUCA, 2008). É com tal estrutura teórica que se pretende descobrir e analisar quais eram os temas propagandísticos produzidos e veiculados na revista pelo grupo de jornalistas que a controlava sob a égide do partido nazista.

\footnotetext{
${ }^{1}$ Tradução minha. No original: "die in der Regel medienvermittelte Formierung handlungsrelevanter Meinungen und Einstellungen politischer oder sozialer Großgruppen durch symbolische Kommunikation und als Herstellung von Öffentlichkeit zugunsten bestimmter Interessen verstanden werden. Propaganda zeichnet sich durch die Komplementarität vom überhöhten Selbst- und denunzierendem Fremdbild aus und ordnet Wahrheit dem instrumentellen Kriterium der Effizienz unter. Ihre Botschaften und Handlungsaufforderungen versucht sie zu naturalisieren, so dass diese als selbstverständliche und nahe liegenden Schlussfolgerungen erscheinen.”
} 


\section{O aparato de controle nazista das publicaçóes ilustradas}

O conteúdo das revistas na Alemanha nazista foi, a partir de 1939, estritamente controlado pelo chamado Zeitschriften-Dienst (Berlim, 1939-1945). Este órgão de imprensa estava ligado ao Ministério da Propaganda de Goebbels e tinha a função de delimitar os assuntos a serem tratados pelas outras revistas no território do Reich, organizando-os em níveis de prioridade (YOUNG, 1987; KOSZYK, 1972). Tal aparato de censura fazia parte de várias medidas amplas tomadas nessa direção desde 1933, quando da nomeação de Hitler ao cargo de chanceler.

O primeiro deles foi a criação da Câmara de Cultura do Reich como parte do Ministério da Propaganda, englobando o controle absoluto do jornalismo por meio da Câmara de Imprensa (KOSZYK, 1972). Outro órgáo de controle foi a chamada "Conferência dos Ministros", presidida por Goebbels, a qual reunia representantes de organizaçôes nazistas, membros do Exército e do Ministério das Relaçôes Exteriores com o propósito de realizar pré-censura de todos os jornais (HAGEMANN, 1970).

Por fim, os decretos outorgados em 1935 pelo chefe de imprensa do partido e diretor da editora central do partido nazista Max Amann (três no total, os quais retiravam os judeus de quaisquer postos de trabalho que ocupassem na área, proibiam sociedades anônimas (AG) e limitadas $(\mathrm{GmbH})$ além de cadeias jornalísticas e podiam cancelar publicaçôes por "sensacionalismo") foram cruciais para suprimir e coibir quaisquer "inimigos" dos nazistas no jornalismo (HALE, 1973), ao mesmo tempo em que criava uma nova face para a profissão, mais adequada e em conformidade com os propósitos da ditadura hitlerista.

No ano de início do conflito europeu, 1939, boa parte da imprensa alemã já havia se tornado propriedade da editora central do NSDAP (FREI; SCHMITZ, 1999), e as revistas passaram a seguir estritas regras de publicação da Zeitschriften-Dienst devido ao novo contexto de guerra, tal como Die Wehrmacht. Não demorou, contudo, para que esta última revista e sua editora, ligadas às Forças Armadas, caíssem nas mãos do partido, que desde 1935 já efetuava fusóes, absorçôes e compras forçadas de editoras e órgãos de imprensa, de forma a realizar o desejo de Amann de tornar a totalidade da imprensa propriedade do NSDAP (FREI; SCHMITZ, 1999).

\section{A fundação de Die Wehrmacht e seu desenvolvimento até 1940}

A revista Die Wehrmacht foi um projeto idealizado pelo general Joachim von Stülpnagel, entáo militar reformado da Reichswehr (exército da República de Weimar), em conjunto com seu primo Hans-Joachim Killisch von Horn e com o tio de sua esposa Arnold Killisch von Horn. Este último era proprietário do jornal Berliner Börsen-Zeitung (Berlim, 1855-1944), 
tradicional periódico de assuntos econômicos na capital alemã, onde Stülpnagel publicava artigos sobre política desde 1924 e do qual se tornou diretor-gerente dez anos depois. Os membros da família von Horn e Stülpnagel foram apoiados pelo então marechal de campo e ministro da guerra Werner von Blomberg com um crédito inicial de 50.000 Reichsmark, o qual provavelmente foi utilizado para a compra e reorganização de uma revista ilustrada existente desde 1935 dedicada ao exército, chamada Das Ehrenkreuz (Berlim, 1935-1936), ${ }^{2}$ bem como para a criação da editora "Die Wehrmacht". Sob tais auspícios ministeriais, Die Wehrmacht foi lançada em cinco de novembro de 1936 com uma tiragem inicial de 90.000 exemplares (FRANZOLIN, 2017).

Com um conteúdo voltado para folhetins sobre a Primeira Guerra Mundial, reportagens sobre uso de novas armas, o cotidiano dos soldados na caserna, guerras e exércitos estrangeiros, Die Wehrmacht alcançou no seu número 13 de 1939 uma tiragem de mais de 630.000 exemplares por número, tornando-se assim um sucesso editorial que só cresceu nos anos seguintes. De acordo com dados de Schmidt (1947), antigo funcionário da Franz Eher Verlag, a editora central do partido nazista, a revista oficial ilustrada das Forças Armadas alcançou sua maior tiragem durante a guerra, com 1.984.164 exemplares vendidos em 1944, tornando-a a segunda maior revista ilustrada, apenas atrás da Berliner Illustrierte Zeitung (Berlim, 1892-1945), a mais famosa publicação ilustrada da Alemanha na época e líder de vendas no mercado revisteiro desde o início do século XX.

Até alcançar tal sucesso já no conflito mundial, a publicação enfrentou grande contratempo. Este se iniciou em dezembro de 1938, quando o estúdio fotográfico Schröter, na cidade de Osnabrück, tentou expandir suas operaçôes a fim de se dedicar exclusivamente a fotografar as Forças Armadas. Para tanto, Schröter desejava se fundir com a editora "Die Wehrmacht", e assim seu pedido foi encaminhado a Max Amann. Em 12 de maio de 1939, já com a posição do NSDAP fortalecida na Alemanha devido às vitórias de Hitler na política exterior e interior, o chefe de imprensa do partido pôde enfim enfrentar o aparato jornalístico das Forças Armadas. Amann não só negou a fusão das duas empresas como ainda assegurou que "as revistas da Wehrmacht deveriam ser publicadas basicamente por editoras do partido" (FRANZOLIN, 2017). A disputa que se seguiu envolveu não apenas Amann de um lado, o qual queria transferir a revista e sua editora para uma das filiais da Franz Eher Verlag, mas também Stülpnagel e o chefe do Alto Comando da Wehrmacht (Oberkommando der Wehrmacht - OKW), o entáo coronel-general Wilhelm Keitel, os quais tentaram manter a independência da publicaçáo frente à absorçáa forçada. O conflito entre as duas partes só foi resolvido em 4 de fevereiro de 1940, quando o próprio Hitler interveio pessoalmente em favor de Amann, aprovando a transferência do periódico e sua editora para

\footnotetext{
${ }^{2}$ A publicação circulou de 2 de outubro de 1935 até outubro de 1936 e trazia, assim, como sua sucessora, farta quantidade de fotos a respeito do novo exército alemão reorganizado em 16 de março de 1935 por Hitler, o qual se tornou Wehrmacht a partir da antiga Reichswehr. Esta publicação não será aqui analisada, pois ultrapassa os limites propostos por este artigo.
} 
a editora central do NSDAP, ao mesmo tempo em que mantinha a influência das Forças Armadas na área editorial e na redação da revista (FRANZOLIN, 2017).

Depois de Max Amann assumir o controle de Die Wehrmacht, pouca coisa se sabe a respeito do funcionamento da redação no período de 1940 a 1944. O cargo de editor-chefe ficou nas mãos de Bernd Overhues (FRANZOLIN, 2017)3 já no início de 1939, o qual desde 1936 trabalhava no periódico enquanto editor assistente. Overhues permaneceu no cargo durante toda a guerra, até o fim da revista. O jornalista supostamente teria sido também o criador do design da revista (DAHLMANN, 1996), e já a partir do número 16 do periódico, em 1941, tornou-se também um soldado das Companhias de Propaganda, escrevendo reportagens para Die Wehrmacht na frente de batalha da União Soviética até a última edição publicada em agosto/setembro de 1944. A respeito dessas unidades especiais das Forças Armadas alemãs, intimamente ligadas à publicação, são necessários maiores esclarecimentos.

\section{O Departamento de Propaganda das Forças Armadas (WPr.), as Companhias de Propaganda (PK) e suas relações com Die Wehrmacht}

Durante a década de 1920 e início da de 1930, especialistas alemães militares e civis discutiram intensamente as causas da derrota do país na Primeira Guerra Mundial, bem como pensaram em soluçôes para que a Alemanha se saísse vitoriosa em um conflito futuro. No geral, tais autores defendiam a presença de uma forte liderança política e militar e também uma melhor organizaçâo da propaganda dentro do país, de forma que inimigos não lograssem êxito em convencer os alemáes da derrota, tal como havia ocorrido com a propaganda inglesa durante o período de 1914 a 1918 (UZIEL, 2008). Estas ideias se coadunavam perfeitamente com o que o alto escaláo do NSDAP tinha em mente - em especial Hitler e Goebbels.

Após a nomeação de Hitler como chanceler por Hindenburg em 1933, os nazistas intensificaram os trabalhos de propaganda dentro das Forças Armadas, que foram reorganizadas em 1935. No entanto, não tardaram os desentendimentos acerca de como as formas de doutrinaçáo deveriam ser mobilizadas em combate. O alto comando da Wehrmacht $(\mathrm{OKW})$ não aceitava jornalistas civis escrevendo sobre temas militares, enquanto o Ministério da Propaganda (Reichsministerium für Volksaufklärung und Propaganda - RMVP), sob o comando de Goebbels, imaginava que propagandistas ligados ao Exército, Marinha e

\footnotetext{
${ }^{3}$ Overhues nasceu em Menden, na província da Vestfália, em 1911. Depois de se mudar para a cidade de Düren, passou a trabalhar como jornalista na editora local, Kaulhamel, de 1931 a 1932, onde adquiriu experiência jornalística. Em 1932 mudou-se para Berlim e lá tornou-se voluntário na editora Ullstein. Um ano depois conseguiu dentro da editora "permissão para atuar como editor". Embora tenha ficado desempregado de 1934 a 1935, foi chamado em 1936 para compor a redação de Die Wehrmacht.
} 
Aeronáutica não possuíam as qualificaçôes técnicas necessárias para o trabalho. As primeiras tentativas de integrar grupos de jornalistas civis na remilitarização da Renânia (1936) e em manobras do Exército (1937) fracassaram, pois toda a estrutura de hierarquia militar, de soldados a oficiais, recusou-se a aceitar a presença de civis.

Finalmente, no fim de 1938 e começo de 1939, foi assinado um acordo de cooperação entre o RMVP e o OKW, que regulou a "Condução da Propaganda na guerra", encerrando, dessa forma, a antiga querela. Assim, foram criadas as chamadas "Tropas/companhias de propaganda" (Propagandakompanien - PK), com treinamento militar oferecido pela Wehrmacht, ao mesmo tempo em que seguiam instruçôes e diretivas enviadas pelo RMVP (UZIEL, 2008). As companhias de propaganda foram responsáveis por criar todo o material jornalístico e propagandístico de 1939 a 1945 (desenhos de combate e caricaturas, reportagens escritas, fotos, filmes, pinturas etc.), que abasteceu o conteúdo das publicaçóes alemãs, incluindo Die Wehrmacht. Esta contava com material exclusivo, fornecido por uma unidade especial das PK, chamada de "Esquadrão de correspondentes para uso especial do Alto Comando do Exército" (Berichterstaffel z.b.V. ObdH.). A unidade era utilizada para atividades de propaganda em regióes específicas das várias frentes de batalha, e contava, dentre outros, com vários membros da redaçáo da revista no período, como o desenhista Theo Matejko; os fotógrafos Gerd Habedanck, Bernd Lohse, Günther Pilz, Friedrich Ucker, Hans Veitl e Bruno Waske; e os jornalistas Jochen Amtor, Heinz Diestelmann, Karl Fischer, Josef Greiner, Kurt Jeschko, Walter Köhler; o romancista e autor de folhetins Clemens Laar, além do próprio editor-chefe Bernd Overhues (FRANZOLIN, 2017). Segundo Rutz (2007), o Esquadrão de Correspondentes para uso especial do Exército era o "Creme dos Soldados-PK", pois criavam materiais de propaganda apenas para revistas publicadas pelo Departamento de Propaganda das Forças Armadas (Abteilung für Wehrmachtpropaganda - WPr.).

O Departamento WPr. foi criado em $1^{\circ}$ de abril de 1939, no interior do Alto Comando da Wehrmacht, em funçấo do crescimento, naquele ano, do número de tropas PK dentro do Exército, Marinha e Aeronáutica. A ele foram acrescentadas todas as atividades de censura militar, bem como o antigo grupo de imprensa do Exército, o qual coordenava as atividades da redação de Die Wehrmacht desde 1936. O Departamento WPr. era dividido em quatro grupos: o Grupo I, responsável pela organização e direcionamento da propaganda; o Grupo II concentrava-se na doutrinação das tropas e na propaganda dentro do território nacional. Este foi o grupo responsável pela supervisão redacional de Die Wehrmacht depois da compra da publicação por Amann. Já o Grupo III respondia pela censura, e o Grupo IV pela propaganda em âmbito internacional. Até 1942, existiram ainda três grupos adicionais (V, VI e VII) dedicados, respectivamente, ao Exército, Aeronáutica e Marinha, cujas atividades foram encampadas naquele ano pelo Grupo II (RUTZ, 2007). 
As duas versóes principais da revista e sua materialidade na guerra (1939-1944)

Durante o conflito, Die Wehrmacht teve duas ediçóes principais: uma edição alemã (Figura 1), publicada de novembro de 1936 a agosto de 1944, que somou 200 números, e 73 números da chamada Ausgabe A (Edição A - Ausland, exterior), destinada à venda e distribuiçáo internacionais (Figura 2), que circulou de dezembro de 1941 a setembro de 1944.

A edição alemá era comercializada em bancas de jornal na Alemanha por 25 centavos de marco (Reichspfennig), o que equivalia a pouco mais que uma xícara de café no ano de 1939 (22 Reichspfennig) e exatamente o mesmo que um tubo de pasta de dentes em 1940, um preço considerado baixo (FRANZOLIN, 2017). Os soldados também recebiam essa edição gratuitamente para ler no front (VOSSLER, 2005). Documentos do Ministério das Relaçôes Exteriores nazista (Auswärtiges $A m t$ ) evidenciam que a edição alemã foi distribuída nos Bálcãs - 50.000 números para exposições em embaixadas alemãs em cidades como Zagreb, Belgrado, Tessalônica e Varna. Mais 4351 números foram distribuídos para adidos militares alemães na Ásia, América do Norte, Sul e Central, além da própria Europa Ocidental e Oriental. As maiores remessas foram enviadas para adidos na Holanda (1.038), Romênia (1.285), Hungria (416) e Estados Unidos, com 1.009 números (FRANZOLIN, 2017).

A penetração do periódico na Eslováquia mostra que a sua leitura pode ter sido ainda mais difundida. A embaixada em Bratislava pediu mil números para distribuição "ao grupo populacional húngaro" do país bem como para "salas de espera de consultórios médicos, dentistas e advogados", além de mais dez mil revistas para escritórios de propaganda eslovacos, sedes de partidos e para a organização para o exterior do NSDAP na Eslováquia (FRANZOLIN, 2017, p. 138).

Figura 1: Capa da edição alemã

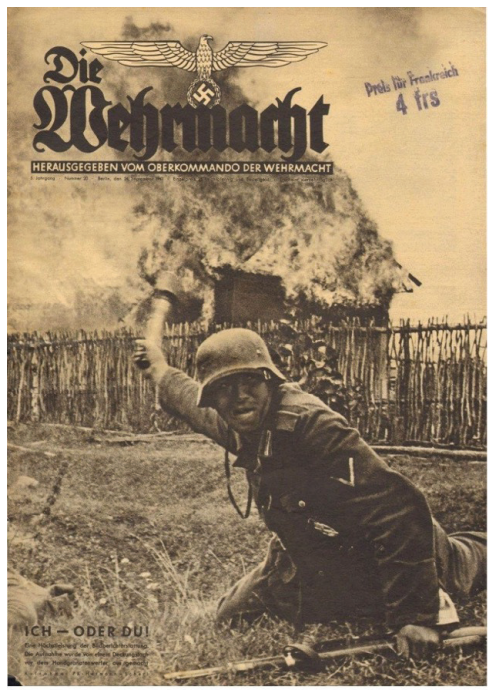

Fonte: Die Wehrmacht, 24 set. 1941. p. 1 (acervo particular) 
Figura 2: Capa da Edição A

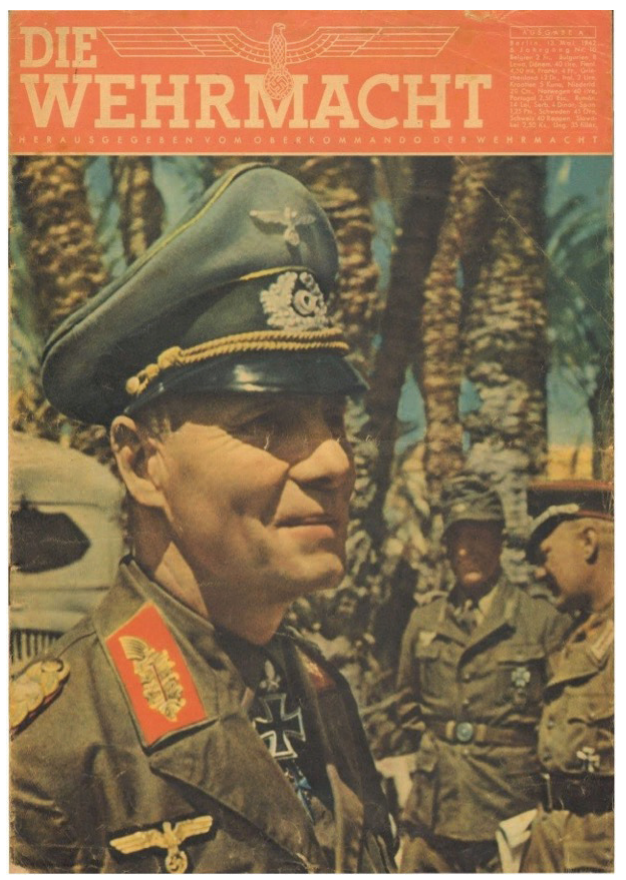

Fonte: Die Wehrmacht Ausgabe A, 13 maio 1942. p. 1 (acervo particular)

O fato de a Eslováquia ter se tornado um Estado satélite dentro da zona de influência nazista após março de 1939, com a incorporação da República Tcheca como protetorado do Reich, pode ajudar a entender o porquê da grande difusão da edição alemã de Die Wehrmacht naquele país.

O enorme interesse das várias embaixadas e de países satélites pelo periódico alemão pode ter sido responsável pela criação, no final de 1941, da edição para o exterior. A Edição A era comercializada em moeda local, e por preços baixos, em bancas de jornal dos seguintes países, os quais apareciam no canto superior direito da capa em cada número: Bélgica, Bulgária, Dinamarca, Finlândia, França, Grécia, Itália, Croácia, Holanda, Noruega, Portugal, Romênia, Sérvia, Espanha, Suécia, Suíça, Eslováquia, Turquia e Hungria, ou seja, países aliados, neutros ou ocupados pela Alemanha. Curiosamente, a revista era escrita inteiramente em alemão, o que provavelmente diminuía de forma considerável seu público leitor. Dessa forma, a Edição A podia alcançar apenas minorias alemãs étnicas em outros países europeus, os chamados Volksdeutsche, representantes e funcionários de embaixadas e legações alemãs e ainda países de língua germânica como a Suíça. É possível supor ainda que "soldados da Wehrmacht e da Waffen-SS estacionados e funcionários da administração nos países ocupados” (RUTZ, 2007, p. 94) teriam lido a revista, mas tropas regulares no front jamais a receberam.

Dentre todos os países onde a Edição A foi comercializada, são da Suíça os melhores dados a respeito da sua vendagem e distribuição. A publicação teve boa recepção do público 
durante 1942: no primeiro trimestre foram entregues 31.152 números, dos quais 16.066 foram vendidos. No segundo, 24.268 exemplares foram enviados para comercialização, 12.479 vendidos. O próprio exército suíço, segundo relatório do Ministério das Relaçóes Exteriores, teria aprovado a publicação: "A edição estrangeira aprimorada, com capa colorida, teve um bom efeito aqui, assim como o fato das autoridades militares recomendarem a leitura desta revista para as tropas" (FRANZOLIN, 2017, p. 139). A continuidade da guerra e as constantes derrotas da Alemanha dificultaram o envio da revista para a Suíça nos anos de 1943 e 1944, diminuindo bruscamente as vendas. Somente 10.530 revistas foram entregues no último trimestre de 1944, e apenas 4.629 foram vendidas. Os relatórios do Auswärtiges Amt comprovam que a Edição A nunca atingiu grande parte da população suíça, mas construiu ao mesmo tempo naquele país um público fiel e regular.

O formato da publicação foi sempre o mesmo na edição alemã e na Edição A: $36,5 \mathrm{~cm} \mathrm{x}$ $26,5 \mathrm{~cm}$. Já o número de páginas da versão germânica sofreu forte redução com o passar dos anos. De 1939 a 1941, a revista circulou com exemplares que variavam de 32 a 24 páginas. No fim do ano de 1941, depois de quatro meses do início da invasão da União Soviética, o montante caiu para 16 na edição de 21 de outubro, e assim se manteve até o número 13 de junho de 1942. Desta data até o último número, datado de 30 de agosto de 1944, a publicação teve somente 12 páginas (Tabela 1). Já existiam instruçôes da Câmara de Imprensa do Reich para o racionamento de 10\% do papel de imprensa desde 1937 (KOSZYK, 1972), mas a produção de explosivos durante o conflito mundial, que exigia celulose, foi priorizada na redistribuição de recursos determinada pelo Estado alemão (FÜHRER, 2008). Tal fato explica porque Die Wehrmacht, assim como outras publicaçóes, experimentaram queda acentuada na paginação nos anos finais do regime nazista.

Tabela 1: Flutuação da paginação da edição alemã de Die Wehrmacht durante a guerra (1939-1944)

\begin{tabular}{|c|c|c|}
\hline $\begin{array}{c}\text { Ano de publicaçáo } \\
\text { (Edição alemã) }\end{array}$ & $\begin{array}{c}\text { No de páginas } \\
\text { (mínimo) }\end{array}$ & $\begin{array}{c}\text { No de páginas } \\
\text { (máximo) }\end{array}$ \\
\hline Jan.1939 a out. 1941 & 24 & 32 \\
\hline Out. 1941 a jun. 1942 & 16 & 16 \\
\hline Jun. 1942 a ago. 1944 & 12 & 12 \\
\hline
\end{tabular}

Fonte: Acervo particular

Situação bem diferente observa-se em relação à versão para o exterior, que tinha como missão convencer os leitores nos países neutros e ocupados da formidável capacidade militar alemá, o que também era atestado, sob outra perspectiva, com a publicaçáo de uma revista de alta qualidade, isso mesmo durante a guerra, inclusive com fotos coloridas. Dessa forma, a Edição A sempre circulou com 24 páginas até o fim em 1944. O periódico internacional publicava 
as mesmas fotorreportagens da Edição $\mathrm{A}$, com algumas poucas especiais a respeito de tropas estrangeiras europeias incorporadas à Wehrmacht nas várias frentes de batalha. A funçáo da Edição A era não só comprovar que a Alemanha vencia em todos os fronts, mas também mostrar que o público estrangeiro, alvo da publicação, supostamente apoiava o esforço de guerra germânico, inclusive fazendo parte das Forças Armadas da Alemanha nazista.

Die Wehrmacht continha, em suas duas versóes, logo nas primeiras páginas, artigos escritos por membros da redação ou por militares de proa do regime, caso do coronel Hasso von Wedel, chefe do Departamento de Propaganda das Forças Armadas (WPr.) e das PK, do general Heinz Guderian, ou, ainda, do marechal de campo Wilhelm Keitel, comandante de toda a Wehrmacht. As páginas do miolo eram reservadas para as fotorreportagens, que apresentaram, durante a guerra, dois momentos distintos: a partir de 1939, já sob o comando de Bernd Overhues, deu-se maior importância às imagens em detrimento dos textos. Se, ainda nos anos 1930, a revista teve problemas para publicar material fotográfico de boa qualidade, estes logo foram resolvidos pela enorme quantidade de fotos produzidas e enviadas pelas PK para a redaçáo. $\mathrm{O}$ uso de mapas permitia aos leitores acompanharem os eventos nos vários fronts, enquanto o recurso a desenhos, que recriavam cenas de batalha, com a evidente intenção de glorificar as açôes dos soldados alemães, tornaram-se muito frequentes. A partir de 1941, teve início a fase mais criativa da publicação, que durou até o fim em 1944. As fotografias passaram a ser ordenadas em sequências complexas, ao mesmo tempo em que artigos que contivessem apenas textos deixaram de figurar no impresso. Os mapas, por seu turno, ganharam em complexidade e se aproximaram de infográficos, com informaçóes detalhadas sobre batalhas e equipamentos, enquanto os desenhos continuavam aclamando as tropas do Eixo, que, naquele momento, recuavam em todas as frentes de batalha.

Além das fotorreportagens, a revista também publicava folhetins. Embora os romances seriados fossem tradicionalmente voltados, nas revistas ilustradas tradicionais alemãs, para o entretenimento e escapismo da difícil realidade sob a ditadura nazista (FÜHRER, 2011), aqueles publicados em Die Wehrmacht serviam para fins propagandísticos, incorporando situaçóes e temas que remetiam a Hitler e ao partido nazista. Eram comuns romances com temas relativos à Primeira Guerra Mundial, histórias de heroísmo e de personalidades militares, ou, ainda, relativas ao conflito em curso. O objetivo era claro: doutrinar os soldados, parcela importante dos leitores da revista, a respeito de suas responsabilidades para com o país e oferecer a eles modelos históricos a serem imitados. O exemplo serviria igualmente para o resto da população que comprava a revista nas bancas. Os folhetins náo estavam presentes na versão destinada ao exterior.

A publicidade é um dos componentes mais importantes de um impresso periódico, uma vez que contribui não apenas para o financiamento, como se constitui em indicativo do público leitor idealizado pelos responsáveis. No caso da versão germânica de Die Wehrmacht, os destinatários principais eram, de um lado, a população alemã adulta, que tinha acesso aos 
exemplares em banca, e também os recrutas que prestavam serviço militar e/ou soldados/oficiais incorporados às Forças Armadas, que podiam ler a revista dentro do território alemão e no front. Pelo menos duas páginas inteiras, com inúmeros anúncios de pequenas empresas, continham reclames de mercadorias tão díspares como canetas tinteiro, lâminas de barbear, barcos militares infláveis, pasta de dentes, medicamentos, armas brancas e de fogo, relógios de pulso, instrumentos musicais (principalmente acordeóes), livrarias, sabonetes, bronzeadores, açougues, uniformes, dentre vários mais. Outras páginas inteiras eram distribuídas por todo o periódico com anúncios das indústrias pesadas de aço, muniçôes, armas, motores, cigarros etc., as quais estavam ligadas ao governo e financiavam as Forças Armadas e, por conseguinte, seu órgão de imprensa oficial. Assim, pode-se imaginar que Die Wehrmacht era mantida pelo governo nazista e pelas Forças Armadas principalmente com dinheiro de empresas ligadas à produção de material bélico. Com a redução de páginas cada vez mais recorrente devido ao agravamento do conflito e o racionamento de todos os produtos do cotidiano no território do Reich (WESTPHAL, 1989), as várias páginas de publicidade desapareceram em 1943 e 1944. Somente alguns poucos anúncios do que havia restado da indústria pesada e das fábricas de medicamentos e cigarros continuaram a ser publicados.

A Edição A possuía os mesmos anúncios das indústrias pesadas e de munição dispostas de forma esparsa por toda a revista de 1941 a 1944, e estes jamais tiveram redução em sua quantidade. Era também uma estratégia de reafirmar para os leitores estrangeiros a "força" das indústrias alemãs, que supostamente continuavam operando sem interrupção mesmo sendo alvo de bombardeios.

\section{O pacto Ribbentrop-Molotov (1939-1940) e a guerra contra a URSS nas reportagens de Die Wehrmacht (1941-1943)}

De todos os países que figuraram nas páginas de Die Wehrmacht, a União Soviética foi o mais criticado de todos. Durante a década de 1930 o país foi considerado uma enigmática ameaça, que poderia destruir náo só a Alemanha mas todo o continente europeu. Com a assinatura do pacto Ribbentrop-Molotov, em 23 de agosto de 1939, as matérias e reportagens na imprensa nazista a respeito da URSS foram interrompidas, o que não ocorreu de todo na revista oficial das Forças Armadas. Em outubro daquele ano, Die Wehrmacht publicou um encontro entre tropas alemãs e soviéticas (agora chamadas de "russas"), que posaram para um desenhista das PK (HABEDANCK; ERDMANN, 1939). Ao fim da guerra russo-finlandesa em 1940, a revista afirmou em artigo que os "russos" somente exigiam dos finlandeses o que correspondia aos seus "interesses militares e econômicos" (DIE WEHRMACHT, 1940, p. 7). Ao chamar os soviéticos tâo somente de "russos", a publicação tentava fazer com que seus leitores esquecessem os constantes ataques desferidos contra a URSS desde 1936, 
numa tentativa de colocar em segundo plano o comunismo, explícito na União das Repúblicas Socialistas Soviéticas, termo que não é utilizado. Essas foram, no entanto, as únicas mençôes, relativamente positivas, presentes enquanto durou o pacto de não agressão.

O avanço das tropas alemãs em território soviético, em 22 de junho de 1941, que deu início à Operação Barbarossa, trouxe consigo renovadas críticas ao país em Die Wehrmacht. A primeira mudança verificada é principalmente semântica, já que se volta a utilizar o termo "soviético", desaparecido desde 1939, para ressaltar a diferença entre o nazismo e o regime comunista vigente na URSS, criando uma dicotomia que foi mais tarde transformada em maniqueísmo. Do ataque em 1941 até a derrota decisiva da Alemanha em Stalingrado, a revista repetiu ad nauseam três narrativas principais.

A primeira delas dizia respeito às constantes mençôes às perdas e derrotas do Exército Vermelho, que tinha por evidente corolário a suposta superioridade alemá no campo de batalha durante o período da chamada "Blitzkrieg". Assim como boa parte do material presente em Die Wehrmacht, o foco principal das fotorreportagens recaía sobre o desenrolar dos acontecimentos militares em si e muito pouco sobre os temas políticos, como atestam texto e imagem (Figura 3), comuns nessa primeira fase do conflito. As forças soviéticas eram menosprezadas:

Uma localidade fronteiriça [...] pode ser nomeada como um símbolo do caráter de aniquilação das lutas que se inflamaram entre nossas tropas atacantes e os exércitos soviéticos cercados nos locais lá a leste de Bialystok já na primeira semana da Campanha do Leste. Diariamente fechou-se, depois de realizada uma arrojada manobra englobante, o apertado círculo de ferro dos atacantes alemães em relação às persistentes, repetidas e ferozes tentativas de rompimento dos chicoteados exércitos soviéticos. Uma localidade depois da outra precisou ser abandonada pelos inimigos. [...] Até aonde o olho alcançava, ofereceu-se uma terrível imagem da devastação e da aniquilação inútil, típicas da condução soviética da guerra (HABEDANCK, 1941, p. 2). ${ }^{4}$

\footnotetext{
${ }^{4}$ Tradução minha. No original: "Ein Grenzort [...] kann als Symbol für den Vernichtungscharakter der Kämpfe genannt werden, die dort zwischen unseren angreifenden Truppen mit den im Räume ostwärts von Bialystok eingeschlossenen Sowjetarmeen bereits in der ersten Woche des Ostfeldzuges entbrannten. Täglich schloß sich, nachdem das kühne Umfassungsmanöver durchgeführt war, der eiserne Ring der deutschen Angreifer enger um die sich hartnäckig verteidigenden und zu wiederholten erbitterten Ausbruchsversuchen aufgepeitschten Sowjetarmeen. Ein Ort nach dem anderen mußte vom Feinde aufgegeben werden. [...] Wohin das Auge reichte, bot sich ein grauenvolles Bild der Verwüstung und sinnlosen Vernichtung, typisch für die sowjetische Kriegführung".
} 
Figura 3: A legenda da foto afirma: "Tempestade de aço no Leste. As "lagartas" dos nossos carros de combate são tão frequentemente bloqueadas por tanques soviéticos destruídos e em chamas, que torna inevitável fazer o desvio da rua" (KILLISCH-HORN, H.v., 1941, p. 1). ${ }^{5}$ Curiosamente, a foto mostra tão somente caminhóes de suprimentos destruídos, mas não tanques soviéticos.

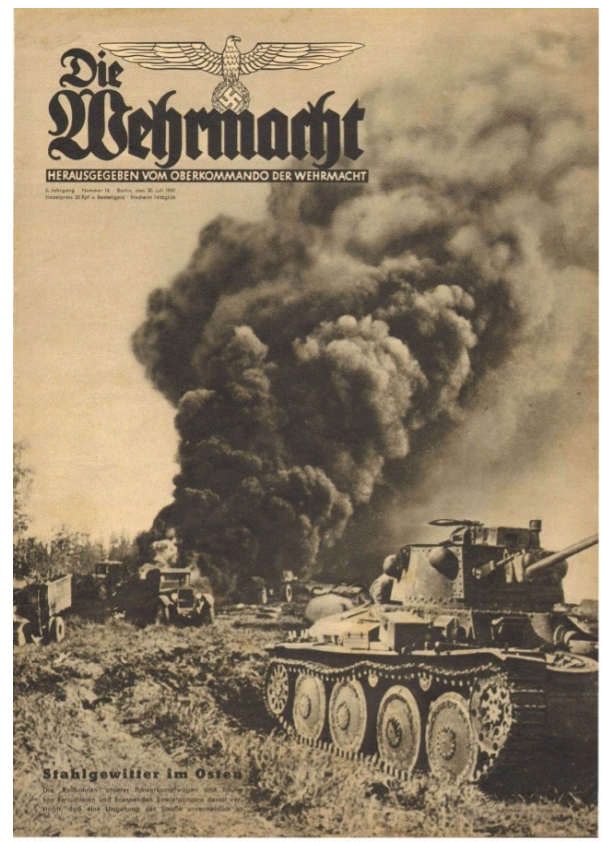

Fonte: Die Wehrmacht, 30 jul. 1941. p. 1 (acervo particular)

O segundo dos três pontos mencionados dizia respeito à quantidade de prisioneiros de guerra, resultado do sucesso inicial da invasão (JAHN, 2003). Embalado pelas conquistas, o periódico publicou em suas páginas, em 1941 e 1942, colunas de prisioneiros, o que comprovava vitoriosa condução alemã na guerra. Imagens desse tipo foram amplamente veiculadas, de forma a atender as exigências da propaganda nazista, que apresentava os soldados capturados como "hordas maltrapilhas", "animais criminosos" ou "massa amorfa" (PAUL, 2004, p. 237). Dessa forma, os ex-combatentes do Exército Vermelho foram quase sempre exibidos em Die Wehrmacht como homens feios, sujos, medrosos e massificados. Os comentários nas legendas das fotos eram curtos e forneciam poucas informações sobre os presos no conflito (Figura 4). Os milhóes de prisioneiros de guerra soviéticos foram maltratados e mal alimentados, em comparação com os de outros países, como Inglaterra e Estados Unidos, já que os eslavos eram definidos, pela visão de mundo nazista, como sub-humanos. Consequência dessa política foi o fato de que a maior parte dos soldados capturados pela Wehrmacht e mortos em cativeiro era soviética (JAHN, 2003).

\footnotetext{
${ }^{5}$ Tradução minha. No original: "Stahlgewitter im Osten. Die "Rollbahnen" unserer Panzerkampfwagen sind häufig von vernichteten und brennenden Sowjetpanzern derart verstopft, daß eine Umgehung der Straße unvermeidlich ist".
} 
Figura 4: As duas fotos pretendiam convencer o leitor do sucesso da invasão da URSS. A primeira, ligeiramente desfocada, apresenta soldados confusos e com medo. O objetivo da foto é reforçado pela legenda: "Um grupo de prisioneiros russo-soviéticos. O horror do fogo de artilharia alemão ainda está nos seus rostos. Tão surpreendentemente começou o fogo de artilharia e o ataque alemão, que alguns dos soldados soviéticos não tinham se vestido”. $\mathrm{Na}$ foto seguinte, uma coluna infindável de prisioneiros tenta demonstrar a força do exército alemão: "Logo depois de algumas horas de combate e já são levados os prisioneiros nestas colunas, como normalmente só se vê depois de dias inteiros de luta” (HABEDANCK; BONESS, 1941, p. 5). ${ }^{6}$

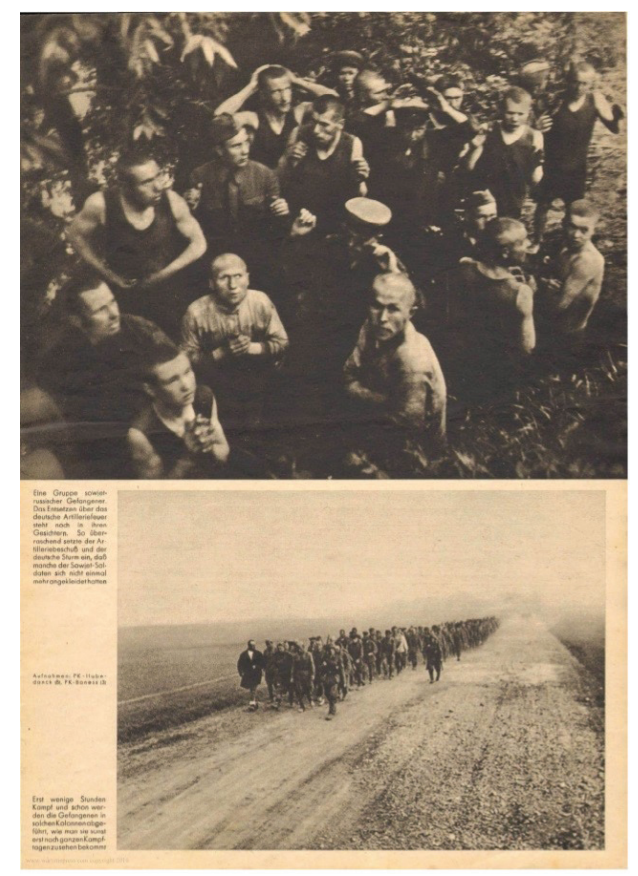

Fonte: Die Wehrmacht, 2 jul. 1941. p. 5 (acervo particular)

A terceira e mais importante narrativa veiculada foi a percepção da URSS enquanto a fonte de todo o "mal" no planeta. Essa ideia maniqueísta começou a ser difundida em 1941 e não deixou mais as páginas da publicação. Intensificou-se após a batalha de Stalingrado, já que era imperativo fortalecer a perseverança de luta da população alemã contra o "mal absoluto". Esse tema figurou não apenas nas fotorreportagens, mas também nos artigos e folhetins do periódico.

No final do ano de 1941, afirmou-se que a União Soviética representava os "poderes da escuridão", dentre os quais predominavam o "materialismo" e o "ateísmo". Os soldados do

\footnotetext{
${ }^{6}$ Traduções minhas. No original: "Eine Gruppe sowjetrussischer Gefangener. Das Entsetzen über das deutsche Artilleriefeuer steht noch in ihren Gesichtern. So überraschend setzte der Artilleriebeschuß und der deutsche Sturm ein, daß manche der Sowjet-Soldaten sich nicht einmal mehr angekleidet hatten".

"Erst wenige Stunden Kampf und schon werden die Gefangenen in solchen Kolonnen abgeführt, wie man sie sonst erst nach ganzen Kampftagen zu sehen bekommt".
} 
Exército Vermelho, enquanto parte desse sistema, eram "hordas fanáticas e animalescas" e por consequência não eram mais humanos (ELLENBECK, 1941, p. 9). Um exemplo posterior mostra como a temática continuou permeando todo o conteúdo da revista e se fez presente até mesmo nos folhetins. Em 1943, foi publicado o romance Ai daqueles que são amados por eles! (Wehe denen, die von ihnen geliebt werden!). Segundo o texto introdutório, o autor, tenente-coronel Poljakow, teria pertencido ao antigo exército estoniano e tornou-se prisioneiro da Wehrmacht em 1943. Ao narrar suas memórias no romance sobre o período em que teria vivido em um "campo de prisioneiros da NKVD (polícia secreta soviética) nos Urais", o autor afirmou que, pouco após uma revolta, teria sido transferido para uma prisão, na qual teve contato com outros prisioneiros estonianos da NKVD. Em conversa sobre a vida em áreas comunistas, o quadro é sombrio:

[...] Se era verdade que na Estônia podia-se comer tanta carne quanto alguém quisesse? Se lá era realidade que as vacas dariam até vinte litros de leite por dia? Se a gente tinha permissáo para viajar até aonde a gente desejasse? Náo havia fim para o questionamento. O fato de eu não poder dizer ao bravo a verdade, pois cada resposta teria sido uma acusação contra a União Soviética, me atormentou como nunca antes (POLJAKOW, 1943, p. 10).?

Assim, a Uniáo Soviética (termo que desde junho de 1941 novamente passou a ser utilizado) era um país sem Deus, onde dominava a NKVD; com o povo submetido à fome e à extrema doutrinação. Desse modo, o que se propunha era uma clara dicotomia: a luta do "bem" (Alemanha) contra o "mal" (URSS). A primeira, sinônimo de paraíso, deveria ser protegida e defendida sob todas as circunstâncias pelos soldados alemães, enquanto a segunda era a representação do próprio inferno, o que justificava sua destruição. Caso a Wehrmacht falhasse nesse intento, as forças do "inferno" iriam destruir para sempre o "paraíso". A luta tomava assim cada vez mais contornos religiosos, o que pode ter desempenhado importante papel no processo de embrutecimento das forças militares e da população alemãs leitoras do periódico.

Comissários políticos do Exército Vermelho apareceram em Die Wehrmacht principalmente enquanto judeus enganadores e fanáticos. Exemplar dessa recorrente temática é o desenho de Theo Matejko, ilustrador oficial da revista. Em "A sede de sangue dos desumanizados" (Blutrausch der Entmenschten), o comissário força os "soldados soviéticos" (uma mulher, um soldado regular e um prisioneiro comum) a lutar até a morte. Devido à doutrinação e opressão do "Politruk" perdem os soviéticos sua humanidade e tornam-se bestas sem sentimento, as quais lutam até seu último respiro (Figuras 5 e 6):

\footnotetext{
7 Tradução minha. No original: “[...] Ob man wirklich in Estland so viel Fleisch essen könne, wie man wolle? Ob dort wirklich die Kühe bis zu zwanzig Liter Milch am Tage gäben? Ob man reisen dürfe, wohin man wünsche? Des Fragens war kein Ende. Daß ich dem Braven nicht die Wahrheit sagen konnte, denn jede Antwort wäre ja ein Vorwurf gegen die Sowjetunion gewesen, quälte mich wie nie”.
} 
O Camarada Comissário, hebreu oriental da mais pura cepa, forçou o seu último grupelho restante de soviéticos até a última resistência em uma pequena cidade já prestes a cair. [...] Junto aos dois últimos companheiros ele invadiu um apartamento, e com raiva brutal empurrou um rifle na mão da mulher - atire, camarada! O camarada condenado levou consigo uma metralhadora, o segundo bolchevique carrega as caixas de munição. [...] Para o condenado tudo é indiferente: ele atira sem pensar e selvagemente pela área, uma intoxicação o invade. E de repente ele precisa rir, ri a risada de uma fera enlouquecida, atiçada pelo comissário de forma a se tornar uma sede de sangue. Cegamente o judeu encara seu adversário, ao qual se dirige o fogo da metralhadora do condenado infectado pela loucura [...] (MATEJKO, 1941, p. $20-21){ }^{8}$

Figuras 5 e 6: Desenho de Theo Matejko sobre os comissários políticos

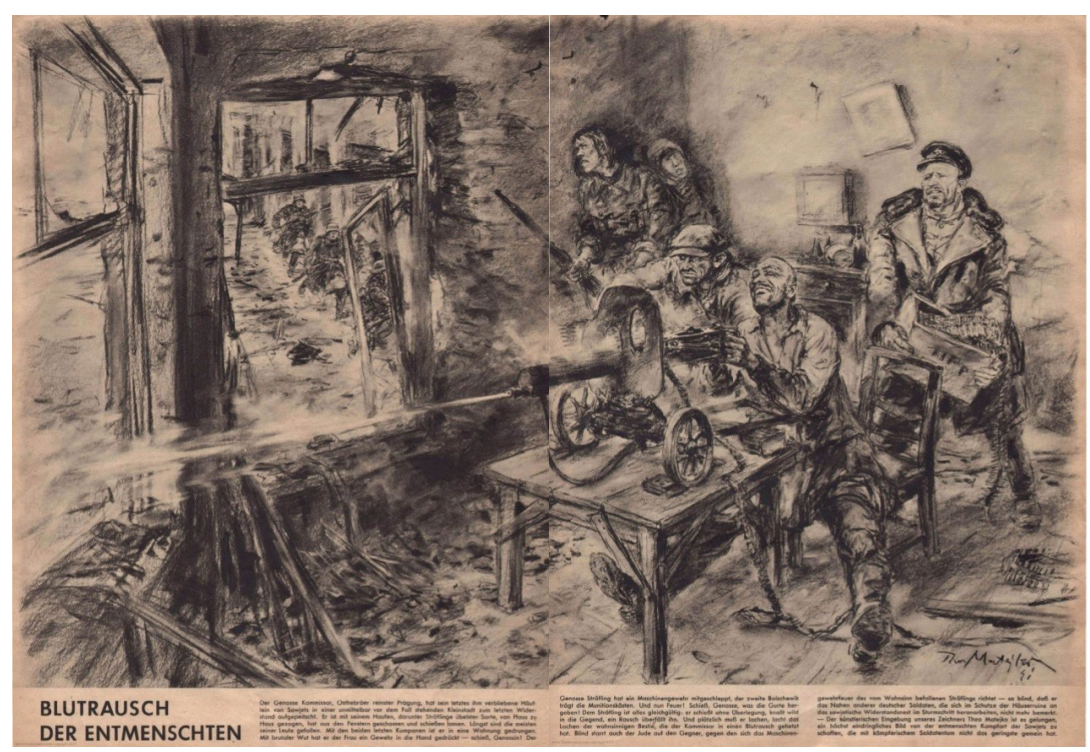

Fonte: Die Wehrmacht Ausgabe A, [dez.] 1941. p. 20-21 (acervo particular)

A desorganização das forças soviéticas, que recrutariam para a luta mulheres e prisioneiros comuns, deveria servir como alerta para leitores da revista sobre a corrupção do regime soviético, que, supostamente, valia-se não só de forças convencionais, mas também de tudo

\footnotetext{
${ }^{8}$ Tradução minha. No original: "Der Genosse Kommissar, Osthebräer reinster Prägung, hat sein letztes ihm verbliebene Häuflein von Sowjets in einer unmittelbar vor dem Fall stehenden Kleinstadt zum letzten Widerstand aufgepeitscht. [...] Mit den beiden letzten Kumpanen ist er in eine Wohnung gedrungen. Mit brutaler Wut hat er der Frau ein Gewehr in die Hand gedrückt - schieß, Genossin! Der Genosse Sträfling hat ein Maschinengewehr mitgeschleppt, der zweite Bolschewik trägt die Munitionskästen. [...] Dem Sträfling ist alles gleichgültig: er schießt ohne Überlegung, knallt wild in die Gegend, ein Rausch überfällt ihn. Und plötzlich muß er lachen, lacht das Lachen der wahnsinnigen Bestie, die der Kommissar in einen Blutrausch gehetzt hat. Blind starrt auch der Jude auf den Gegner, gegen den sich das Maschinengewehrfeuer des vom Wahnsinn befallenen Sträflings richtet [...]."
} 
que tivesse à disposição, indicativo da iminente falência do regime. A representação do comissário político na revista foi, assim, semelhante à das diretrizes gerais da propaganda nazista, que estabelecia ser aquele um "funcionário do partido de uniforme". O Politruk era, ainda, "judeu, mentiroso, atormentador, assassino etc." (FÖRSTER, 1994, p. 148).

\section{Variaçóes na propaganda em relação a desertores do Exército Vermelho, soldados feridos e cossacos (1942-1943)}

Em 1942, continuaram a ser publicados artigos que festejavam as vitórias da Wehrmacht, mas já se observa certa mudança no tom das reportagens, pois a revista chegou a reconhecer a capacidade do Exército Vermelho na preparação e realização de grandes operaçóes militares, como ocorreu durante a ofensiva alemã, no verão de 1942, em direção ao Cáucaso. Nessa época surgiram as primeiras reportagens sobre "lutas defensivas" contra a URSS, que se tornariam comuns após Stalingrado. Ainda que de forma sutil, os propagandistas alemães são obrigados a admitir perdas:

Depois de Voronezh e Voroshilovgrad caiu em 24 de julho a mais importante Rostov [...] Os alemães e soldados aliados enfrentaram em frente e em Rostov um inimigo numericamente forte, pois os restos das tropas derrotadas em Voroshilovgrad retiraram-se para Rostov a fim de dar um basta definitivo à ofensiva alemã. No entanto, dentro de três dias as fortificações foram rompidas e a cidade limpa até o último inimigo [...] (OVERHUES; PILZ; WASKE, 1942, p. 7).9

Embora os soviéticos fossem definidos como sub-humanos, para os quais se usavam termos como "animalesco", "hordas", "animais" e "bestiais", foram representados a partir de 1942 de forma contraditória pelos propagandistas da publicação, que passaram a mostrar certa simpatia por desertores e soldados feridos do Exército Vermelho (RUTKOWSKI, 1942), bem como aqueles que apoiavam a causa nazista nos territórios russos, como alguns grupos de cossacos incorporados à Wehrmacht (BOHNEN, 1943).

Uma das reportagens mais emblemáticas nesse sentido foi publicada em 1943. Nela criticava-se a brutalidade dos comissários políticos e o Estado soviético, os quais ameaçavam e pressionavam os soldados que se recusavam a lutar. As fotos mostravam os rostos dos desertores ao mesmo tempo em que as legendas contavam suas histórias pessoais familiares,

\footnotetext{
${ }^{9}$ Tradução minha. No original: "Nach Woronesch und Woroschilowgrad fiel am 24. Juli das wichtigere Rostow [...] Die deutschen und verbündeten Soldaten sahen sich vor und in Rostow einem zahlenmäßig starken Feind gegenüber, denn die Reste der bei Woroschilowgrad geschlagenen Truppen hatten sich auf Rostow zurückgezogen, um hier der deutschen Offensive ein endgültiges Halt zuzurufen. Innerhalb von drei Tagen jedoch waren die Befestigungen durchstoßen und die Stadt vom letzten Feind gesäubert [...]”.
} 
com todos os meios estilísticos de uma Human-Interest-Story (GRANATO, 2002) forte e emocionalmente carregada (Figura 7):

Dois camponeses dos arredores de Moscou contam: [...] na frente de nós a morte! O inimigo com suas horríveis metralhadoras! Atrás de nós a morte! Comissários com pistolas-metralhadoras! E continua gritando atrás de nós: 'Em frente, seus cães preguiçosos!' [...] Um trabalhador do Turquestão, o qual desertou para as linhas alemãs e já identificado com a marca "D", afirma: [...] 'pai: morto, mãe: morta, esposa: morta, crianças: em algum lugar, não podem ser encontradas. 'Retire-se, elas agora pertencem ao Estado', disse o comissário [...] (WASKE, 1943, p. 4). ${ }^{10}$

A crítica feita pelos desertores ao comunismo deveria servir de alerta para os leitores de Die Wehrmacht, pois algo parecido aconteceria caso a guerra não fosse vencida pela Alemanha. Reportagens como esta reforçavam ainda mais a terceira narrativa da revista a respeito da URSS como a fonte de onde todo o mal era proveniente. A esta imagem criada pelos propagandistas somava-se, nesse caso, violência dos Politruks contra os soldados, bem como fome, separação de famílias e abandono, definindo com formas mais precisas a União Soviética enquanto um "inferno" na Terra.

Figura 7: Human-Interest-Story sobre desertores do Exército Vermelho

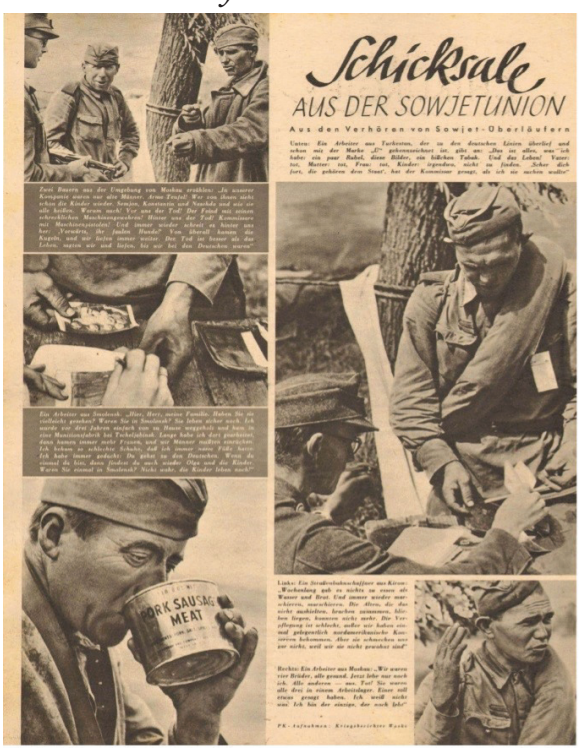

Fonte: Die Wehrmacht, 8 set. 1943. p. 4 (acervo particular)

${ }^{10}$ Tradução minha. No original: "Zwei Bauern aus der Umgebung von Moskau erzählen: '[...] Vor uns der Tod! Der Feind mit seinen schrecklichen Maschinengewehren! Hinter uns der Tod! Kommissare mit Maschinenpistolen! Und immer wieder schreit es hinter uns her: ,Vorwärts, ihr faulen Hunde!' [...] Ein Arbeiter aus Turkestan, der zu den deutschen Linien überlief und schon mit der Marke „Ü“ gekennzeichnet ist, gibt an: [...] 'Vater: tot, Mutter, tot, Frau: tot, Kinder: irgendwo, nicht zu finden. 'Scher dich fort, die gehören dem Staat', hat der Kommissar gesagt [...]." 


\section{"Hordas" e "massas" de "forças superiores" contra os "bravos" granadeiros alemães (1943-1944)}

Depois da derrota e subsequente desastre e captura do sexto exército alemáo em Stalingrado, a imagem dos soviéticos na publicação alterou-se novamente. A partir desse evento decisivo continuaram eles a ser referidos em Die Wehrmacht por meio de termos como "massa" (que já havia figurado nos anos iniciais da guerra no Leste), mas também por outros novos como "inundaçáo" e "forças superiores". Agora eram as forças militares da URSS capazes de planejar e executar grandes ataques contra as posiçóes alemâs, mas ainda assim sempre perdiam a luta no último minuto. Tal foi o modelo narrativo que passou a se repetir em quase todas as reportagens da publicação até o fim em 1944, distanciando cada vez mais a revista da realidade do front:

[...] T 34 queimam! [...] E eles mordem a cada metro que ganham, mas são contestados pelos resistentes e obstinados granadeiros. ${ }^{11}$ Somente sua massa fez com que até o meio-dia os granadeiros - as armas brancas falaram por último - fossem pressionados de volta e obrigados a invadir uma vila. Ainda assim o fogo de artilharia inimigo quase não diminuiu. [...] Mas então vieram os Tiger! [...] Os gritos de urra dos atiradores soviéticos silenciaram. Agora atacam granadeiros alemães... (JOOS; ARLART, 1944, p. 3). ${ }^{12}$

Sutilmente, os propagandistas da revista passaram a reconhecer algum valor nas tropas soviéticas, ao mesmo tempo em que admitiam certas perdas. Além disso, na concepção do Exército Vermelho enquanto "forças superiores", escondia-se, no entanto, renovada crítica ao comunismo soviético, a qual já havia aparecido de forma parecida no começo da guerra na frente oriental. Os homens que lutavam pela Uniáo Soviética agiam não como indivíduos, mas como uma "massa" ou "inundação" de marionetes e seres robotizados, os quais não passavam de meras ferramentas a serviço de Stalin. Dessa forma pretendia-se fortalecer a capacidade e vontade de resistência da população alemã e dos leitores da publicação, pois uma vitória da URSS significaria a transformação de todos os alemães em "massas incons-

\footnotetext{
${ }^{11}$ Os granadeiros eram originalmente soldados de infantaria especializados no lançamento de projéteis, precursores das atuais granadas de mão. Durante a Segunda Guerra Mundial, o termo "granadeiro" passou a ser utilizado para os infantes a partir de 1942, porém só ganhou maior conotação propagandística em 1944, quando passaram a ser chamados de "granadeiros do povo" (Volksgrenadier), de forma a sublinhar a "união" da Wehrmacht com a população alemã.

${ }^{12}$ Tradução minha. No original: “[...] T 34 brennen! [...] Und sie beißen sich heran, jeden Meter, den sie gewinnen, von den zäh und verbissen kämpfenden Grenadieren streitig gemacht. Nur ihre Masse macht es aus, daß sie die Grenadiere bis zum Mittag - die blanken Waffen haben zuletzt gesprochen - zurückdrücken und in ein Dorf eindringen. Immer noch hat sich das feindliche Artilleriefeuer kaum gemindert. [...] Aber dann kommen die Tiger! [...] Das Hurräh der sowjetischen Schützen ist verstummt. Jetzt greifen deutsche Grenadiere an...”.
} 
cientes". Mais do que isso, respeitar o inimigo era também aqui uma estratégia para poder continuar a luta.

No entanto, diferentemente do que era afirmado nas reportagens, nas quais uma imagem idealizada de heroísmo, vontade de resistir e coragem dos soldados alemães era mostrada, lutaram na realidade somente alguns soldados e oficiais fanatizados até o fim, enquanto outros tentaram se salvar e com isso fugiram das ideias propagadas pelo regime de heroísmo e sacrifício (BEHRENBECK, 1996). Os combates apresentados em Die Wehrmacht tornaram-se assim ainda mais desconectados da realidade justamente em uma revista dedicada em sua maior parte, desde o princípio, a temas militares e às várias frentes de batalha. Além disso, palavras como "retirada" ou "derrota" jamais foram citadas, mas as imagens das fotorreportagens transmitiam ao leitor o péssimo estado das forças alemãs. As fotos comprovavam que a Wehrmacht já havia perdido a guerra. Pequenos grupos de soldados atacavam desesperadamente tanques soviéticos usando lançadores de foguetes (Panzerfaust) (Figuras 8 e 9), enquanto marinheiros da Kriegsmarine eram utilizados em terra como tropas regulares por falta de embarcaçóes. Embora a propaganda nazista afirmasse o contrário, faltavam aos combatentes alemães armas, unidades motorizadas e pessoal qualificado. O exército, marinha e aeronáutica vivenciavam franco declínio em termos pessoais, materiais e profissionais (KUNZ, 2002). Não só Die Wehrmacht se distanciou da realidade. Nas últimas revistas ilustradas germânicas ainda existentes nos anos de 1944 e 1945 constatam-se os mesmos problemas, ou seja, nelas figuram histórias exageradas e implausíveis de lutas "vitoriosas" na derrota (VIETH, 2002). Esta foi uma característica da propaganda nazista nos últimos momentos de agonia do regime hitleriano.

O distanciamento da realidade aparecia igualmente em outra temática recorrente nos anos de vitória, aqui mantida para corroborar a ideia do exército alemão "vencedor". Algumas reportagens ainda mostravam a captura de alguns soldados e pilotos soviéticos (Figura 10) em plena expansão do Exército Vermelho na Europa Oriental e na Alemanha do Leste, de forma a também manter a moral, vontade de resistir e coesão dos leitores civis e militares da publicação (KOERBER, 1943). 
Figuras 8 e 9: Embora as fotos e legendas tentem alegar “vitórias” alemãs, é patente o despreparo e desorganização dos soldados, os quais lutam a pé contra tanques e outras forças mecanizadas soviéticas apenas portando lançadores de foguetes. Na página esquerda, na segunda foto à direita, a legenda tenta alterar o que se vê nas imagens usando-se da narrativa comum após Stalingrado: "A tentativa de rompimento foi frustrada. Um T-34 permanece literalmente próximo ao outro. A fumaça ascendente dos tanques abatidos escurece o sol. Entre os destroços dos T-34 atacam os granadeiros blindados SS os inimigos" (GRÖNER, 1944, p. 6). ${ }^{13}$

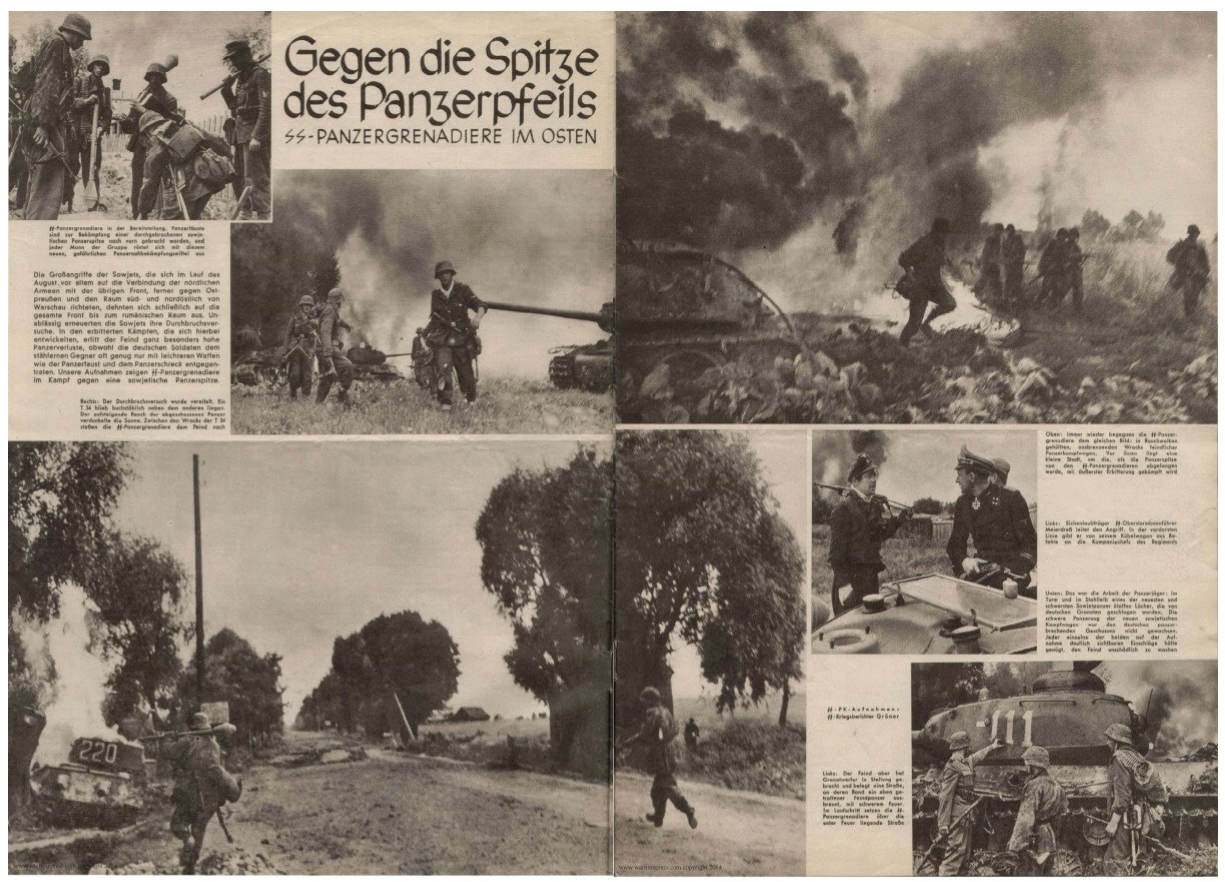

Fonte: Die Wehrmacht Ausgabe A, 6 set. 1944. p. 6 (acervo particular)

\footnotetext{
13 Tradução minha. No original: "Der Durchbruchsversuch wurde vereiltelt. Ein T 34 blieb buchstäblich neben dem anderen liegen. Der aufsteigende Rauch der abgeschossenen Panzer verdunkelte die Sonne. Zwischen den Wracks der T 34 stoßen die SS-Panzergrenadiere dem Feind nach”.
} 
Figura 10: Na última foto abaixo, à esquerda, um pequeno grupo de soldados do Exército Vermelho é feito prisioneiro pelos alemães, mesmo estando estes últimos em inferioridade numérica e visivelmente abatidos nas outras imagens. A legenda da foto dos capturados afirma: "O avanço na linha principal de batalha alemã termina com a marcha para o Oeste, a passagem para o cativeiro. Exaustos e derrotados, arrastando junto os feridos com eles, os soviéticos abandonam o campo de batalha" (KOERBER, 1943, p. 6). ${ }^{14}$

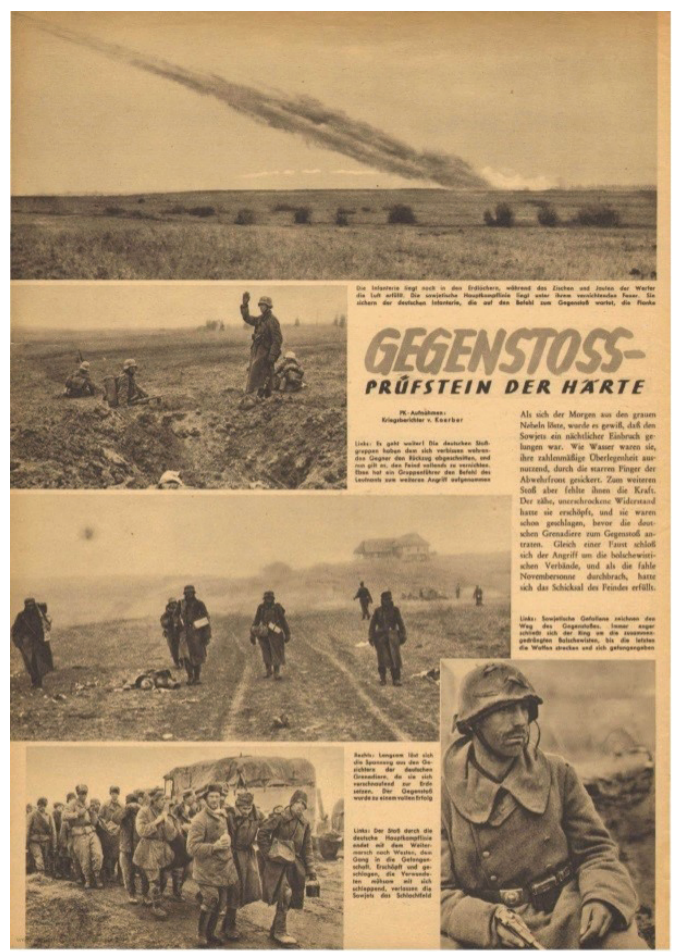

Fonte: Die Wehrmacht Ausgabe A, 24 nov. 1943. p. 6 (acervo particular)

\section{Conclusão}

Em 1939 e 1940, a revista apenas publicou duas reportagens sobre a União Soviética durante a vigência do pacto Molotov-Ribbentrop. Ambas apresentavam os soviéticos enquanto "russos", uma estratégia semântica usada para fazer os leitores esquecerem-se do regime comunista soviético, e para verem com bons olhos as reivindicações daquele país na esfera política internacional.

Depois da invasão da URSS, reportagens de Die Wehrmacht no ano de 1941 seguiram as linhas gerais da propaganda nazista elaborada para toda a população no início da Opera-

\footnotetext{
${ }^{14}$ Tradução minha. No original: "Der Stoß durch die deutsche Hauptkampflinie endet mit dem Weitermarsch nach Westen, dem Gang in die Gefangenschaft. Erschöpft und geschlagen, die Verwundeten mühsam mit sich schleppend, verlassen die Sowjets das Schlachtfeld”.
} 
ção Barbarossa, a qual definiu os soviéticos enquanto "asiáticos primitivos e sub-humanos eslavos". Alguns elementos racistas sumiram da propaganda para o Leste nos anos de 1942 e 1943, possibilitando criar reportagens mais simpáticas na revista a respeito de soviéticos desertores, feridos ou de outros grupos étnicos russos que se uniram aos nazistas. O racismo anterior teve que ser deixado parcialmente de lado também devido ao cada vez maior contato da população e soldados alemães com trabalhadores levados da URSS para a Alemanha e outros territórios ocupados pelo Reich, além do contato dos povos locais com tropas de ocupação germânicas. Mesmo assim, tropas soviéticas regulares continuaram sendo chamadas de "hordas", "bestas" e "massas" até o fim da publicação.

O periódico também apostou no maniqueísmo religioso como forma de atacar a União Soviética. A Alemanha representava o bem e era uma espécie de "Paraíso", enquanto a URSS seria agente do mal e da destruição do mundo, portanto o "Inferno". Até 1943, não importando os meios que utilizassem para combater, nada podiam fazer os soviéticos contra a maquinaria de guerra alemã. Caminhōes, trens, tanques e outros materiais bélicos destruídos, além de colunas intermináveis de maltrapilhos prisioneiros de guerra faziam parte da propaganda veiculada de forma a corroborar tal ideia.

Desde 1942, com a ofensiva alemã no Cáucaso, percebe-se mudança na linha editorial, que passa a reconhecer sutilmente derrotas e também a capacidade de combate do Exército Vermelho, mas a mudança mais importante só ocorreu em 1943, quando o fim da batalha de Stalingrado selou o destino da Alemanha nazista. Em Die Wehrmacht a Alemanha tornou-se o último bastião da cultura e da civilização ocidentais contra as forças "desintegrantes" soviéticas, e passou a lutar uma desesperada guerra defensiva contra "forças superiores" inimigas. Embora sempre "vencessem", as já desgastadas Forças Armadas alemãs não tinham como disfarçar a falta de material e preparo necessários, bem como o desespero e tristeza de seus soldados nas fotografias, por mais que as legendas tentassem alterar o que se via nelas. Assim adentrou a revista um mundo de ilusão, o qual não acompanharia por muito tempo. Em agosto/setembro de 1944 foram publicadas as últimas ediçôes da revista, enfim fechada por Goebbels (FRÖHLICH, 1995) a fim de poupar matérias-primas essenciais para enfrentar uma guerra já há muito perdida. Observa-se assim o dinamismo da linha editorial da revista, que flutuava ao sabor dos acontecimentos da guerra.

\section{Fontes documentais}

\section{Die Wehrmacht (Edição alemã)}

ELLENBECK, Major Dr. Kriegsweihnacht 1941. Die Wehrmacht, n. 26, p. 9, 17 dez. 1941.

ENDET FEUER! Zum Abschluß des russisch-finnischen Krieges. Die Wehrmacht, n. 7, p. 7, 27 mar. 1940. 
HABEDANCK, PK-Gerd; BONESS, PK. Der Krieg im Osten. Nacht vor Brest-Litowsk. Die Wehrmacht, n. 14, p. 2-5, 2 jul. 1941.

HABEDANCK, PK-Gert; ERDMANN, PK-Erhard. An der deutsch-russischen Interessengrenze. Die Wehrmacht, n. 22, p. 6-7, 25 out. 1939.

HABEDANCK, PK-Gerd. Brandfackel im Osten. Die Wehrmacht, n. 15, p. 2-3, 16 jul. 1941.

JOOS, PK-Hermann; ARLART, PK-Hans: Grenadiere. Die Wehrmacht, n. 4, p. 2-3, 16 fev. 1944.

KILLISCH-HORN, H.v. Stahlgewitter im Osten. Die Wehrmacht, n. 16, p. 1, 30 jul. 1941. BOHNEN, PK. Unsere „Kosaken“. Die Wehrmacht, n. 13, p. 4-5, 16 jun. 1943.

LEßMANN, PK; CANTZLER, SS-PK. Im Zuge der Vernichtungsschlachten. Die Wehrmacht, n. 23, p. 15, 5 nov. 1941.

POLJAKOW, Primeiro-tenente. Wehe denen, die von ihnen geliebt werden! Fortsetzung und Schluß. Die Wehrmacht, n. 13, p. 10-11, 16 jun. 1943.

WASKE, PK. Schicksale aus der Sowjetunion. Aus den Verhören von Sowjet-Überläufern. Die Wehrmacht, n. 19, p. 4, 8 set. 1943.

Die Wehrmacht (Edição para o exterior - Edição A)

GRÖNER, SS-PK. Gegen die Spitze des Panzerpfeils. SS-Panzergrenadiere im Osten. Die Wehrmacht Ausgabe A, n. 18, p. 6-7, 6 set. 1944.

KOERBER, PK-v. Gegenstossprüfstein der Härte. Die Wehrmacht Ausgabe A, n. 24, p. 6, 24 nov. 1943.

MATEJKO, Theo. Blutrausch der Entmenschten. Die Wehrmacht Ausgabe A, n. 26, p. 2021, [dez.] 1941.

OVERHUES, PK-Bernd; PILZ, PK-Günther; WASKE, PK-Bruno. Über die Barrikaden... Der Sturm auf Rostow. Die Wehrmacht Ausgabe A, n. 17, p. 6-10, 19 ago. 1942.

RUTKOWSKI, PK. Ausgestossene der Sowjets. Die Wehrmacht Ausgabe A, n. 21, p. 20, 14 out. 1942.

\section{Referências}

BEHRENBECK, Sabine. Der Kult um die toten Helden. Nationalsozialistische Mythen, Riten und Symbole 1923 bis 1945. Vierow bei Grafswald: SH-Verlag, 1996.

BUSSEMER, Thymian. Propaganda. Konzepte und Theorien. Wiesbaden: VS, 2008. 
DAHLMANN, Helmut. Einer der Letzten der ersten Stunde. DJV-Journal, Recklinghausen, n. 2, p. 10-13, 1996.

DUSSEL, Konrad. Bilder als Botschaft. Bildstrukturen deutscher Illustrierter 1905-1945 im Spannungsfeld von Politik, Wirtschaft und Publikum. Colônia: Herbert von Halem Verlag, 2019.

FÖRSTER, Jürgen. Zum Rußlandbild der Militärs 1941-1945. In: VOLKMANN, HansErich (org.): Das Russlandbild im Dritte Reich. Colônia: Böhlau, 1994. p. 141-163.

FRANZOLIN, João Arthur Ciciliato. "Die Wehrmacht". Die offizielle illustrierte Propagandazeitschrift der deutschen Wehrmacht für das In- und Ausland (1936-1944). Tese (Doutorado em História) - Seminar für Geschichte und Geschichtsdidaktik, EuropaUniversität Flensburg, Flensburg, 2017. Disponível em: https://www.zhb-flensburg. de/fileadmin/content/spezial-einrichtungen/zhb/dokumente/dissertationen/ciciliatofranzolin/ciciliato-franzolin-joao-2018.pdf. Acesso em: 29 mar. 2020.

FREI, Norbert; SCHMITZ, Johannes. Journalismus im Dritten Reich. Munique: Beck, 1999.

FRÖHLICH, Elke (org.). Die Tagebücher von Joseph Goebbels. Teil II: Diktate 1941-1945. Band 13: Juli- September 1944. Munique: Saur, 1995.

FÜHRER, Karl Christian. Medienmetropole Hamburg. Mediale Öffentlichkeiten 19301960. Hamburgo: Dölling und Galitz, 2008.

FÜHRER, Karl Christian. Pleasure, Practicality and Propaganda: Popular Magazines in Nazi Germany, 1933-1939. In: SWETT, Pamela E.; ROSS, Corey; D’ALMEIDA, Fabrice. (orgs.). Pleasure and Power in Nazi Germany. New York: Palgrave Macmillan, 2011. p. 132153.

GRANATO, Len. Newspaper Feature Writing Revised Edition. Sydney: University of New South Wales Press, 2002.

HAGEMANN, Jürgen. Die Presselenkung im Dritten Reich. Bonn: H. Bouvier Verlag, 1970. HALE, Oron J. The Captive Press in the Third Reich. Princeton: Princeton University Press, 1973.

JAHN, Peter. Deutsche und sowjetische Kriegsgefangene im Zweiten Weltkrieg. In: BLANK, Margot (org.). Beutestücke. Kriegsgefangenen in der deutschen und sowjetischen Fotografie 1941-1945. Berlim: Ch. Links, 2003. p. 10-15.

KOSZYK, Kurt. Deutsche Presse 1914-1945. Geschichte der deutschen Presse Teil III. Berlim: Colloquium Verlag Otto H. Hess, 1972.

KUNZ, Andreas. Die Wehrmacht in der Agonie der nationalsozialistischen Herrschaft 1944/45. Eine Gedankenskizze. In: HILLMANN, Jörg; ZIMMERMANN, John (orgs.). Kriegsende 1945 in Deutschland. München: Oldenbourg, 2002. p. 97-114. 
LUCA, Tania Regina de. História dos, nos e por meio dos periódicos. In: PINSKY, Carla Bassanezi (org.). Fontes históricas. São Paulo: Contexto, 2005. p. 111-153.

LUCA, Tania Regina de. A Revista do Brasil (1916-1944): notas de pesquisa. In: FERREIRA, Antônio Celso; LUCA, Tania Regina de; BEZERRA, Holien Gonçalves (orgs.). O historiador e seu tempo. São Paulo: Editora UNESP/ANPUH, 2008. p. 117-127.

NITZ, Wenke. Führer und Duce. Politische Machtinszenierungen im nationalsozialistischen Deutschland und im faschistischen Italien. Colônia: Böhlau, 2013.

PAUL, Gerhard. Bilder des Krieges - Krieg der Bilder. Die Visualisierung des modernen Krieges. Paderborn: Schöningh/München: Fink, 2004.

RUTZ, Rainer. Signal. Eine deutsche Auslandsillustrierte als Propagandainstrument im Zweiten Weltkrieg. Essen: Klartext Verlag, 2007.

SCHARNBERG, Harriet. Die "Judenfrage" im Bild. Der Antisemitismus in nationalsozialistischen Fotoreportagen. Hamburgo: Hamburger Edition, 2018.

(SCHMIDT, Fritz). Presse in Fesseln. Eine Schilderung des NS-Pressetrusts. Berlim: Verlag Archiv und Kartei, [1947].

UZIEL, Daniel. The propaganda warriors: the Wehrmacht and the consolidation of the German home front. Berna: Peter Lang, 2008.

VIETH, Eva. Die letzte "Volksgemeinschaft“ - das Kriegsende in den Bildern einer deutschen Illustrierten. In: HILLMANN, Jörg; ZIMMERMANN, John (orgs.). Kriegsende 1945 in Deutschland. München: Oldenbourg, 2002. p. 265-285.

VOSSLER, Frank. Propaganda in die eigene Truppe. Die Truppenbetreuung in der Wehrmacht 1939-1945. Paderborn: Ferdinand Schöningh, 2005.

WELCH, David. The Third Reich. Politics and Propaganda. Second Edition. Londres: Routledge, 2002.

WESTPHAL, Uwe. Werbung im Dritten Reich. Berlim: Transit, 1989.

YOUNG, Robert G. 'Not This Way Please!' Regulating the Press in Nazi Germany. Journalism \& Mass Communication Quarterly, Londres, v. 64, n. 4, p. 787-792, 1987. 